\title{
Different Strokes: American Muslim Scholars Engage Media and Politics in the Woke Era
}

\author{
Jibril Latif ${ }^{1}$ (1)
}

Accepted: 25 May 2021/Published online: 12 June 2021

(C) The Author(s), under exclusive licence to Springer Science+Business Media, LLC, part of Springer Nature 2021

\begin{abstract}
American Muslim intercommunal disunity (fitnah) is exemplified by an emic event when an editorial foray contests the inherited legacies of black Muslim icons like Malcolm X and Muhammad Ali, which exigently compels "diplomats" of different minds into engaging the digital public square with calculated strokes. The woke era's partisan identity politics asymmetrically curtail acceptable expressions of religious authority on issues of race, religion, and politics. Hence, scholars spend their social capital as political actors in these ultracrepidarian environments to different ends. This multi-year study conducted across global sites analyzes scholars with dissimilar approaches to media and political engagement amidst an environment characterized by weaponized media, polarization, and shifting goal posts. Participant observation and textual analysis impart scenes of scholars with fraught associations to administrations, funding sources, and feuding authoritarian Arab regimes getting embroiled in geopolitical hostilities. With mainstream American Muslim narratives aligned with mainstream media's liberal filter bubbles, scholars impact consensus building with varying levels of success; those negotiating compromise within spheres of legitimate contestation and consensus ad interim maintain subsisting influence. However, those that do not are expurgated and thereby cede influence.
\end{abstract}

Keywords Islam $\cdot$ America $\cdot$ Media $\cdot$ Woke $\cdot$ Race $\cdot$ Politics

\section{Introduction}

At the turn of the century, celebrity chef Jamie Oliver, known as the Naked Chef, pared back cooking to its essentials, presenting food in a naked and raw format relatable to viewers. Based on Oliver's moniker, ex-UK Ambassador to Lebanon

Jibril Latif

Latif.j@gust.edu.kw

1 Mass Communications Department, Gulf University for Science and Technology, Block 5,

Building 1, Mubarak Al-Abdullah Area/West Mishref, Hawally, Kuwait 
Tom Fletcher (2016) made an observation after working with "the last paper-andpen prime minister, Tony Blair; the first email prime minister, Gordon Brown; and the first iPad prime minister, David Cameron" that diplomatic survival necessitated evolving from "an intimate typist" into a "Naked Diplomat" by using platforms like Twitter. Regarding "iDiplomacy" and the soft power it garners, he tells the Irish Times, "Whether it was Hezbollah or people on the street, they would tweet at me and they would be stunned to get a reply...[it] allowed me to reach a much bigger set of people with my messages" (Cormaic, 2016). However, American Muslims are a balkanized community that lacks a singular uniting consensus issue. In fact, one would be right to question if Muslims in America-who have never been unerringly monolithic_even constitute an actual community when issues like the Rohingya genocide in Burma, or the Chinese Communist Party's treatment of Uighurs cannot unify adherents. Eugene Robinson proposes a germane thesis about disintegration, that we have the same odds of reassembling a putative "black America" today that Turkey would have trying to reassemble the Ottoman Empire (Robinson, 2010). From an extrapolated view, anti-Federalists presciently argued that factionalism would eventually lead to disintegration of the republic, against Federalist claims that it encouraged consensus through debate. Polling confirms that Democrats have shifted far left in the woke era, but also societally, it confirms that "the general electorate is becoming more liberal"; these shifts impact traditional religious morality and its interlocutors (Sach, 2019). Amidst this backdrop, this paper examines the different strokes of "diplomats" in the American Muslim community as they incorporate dissimilar degrees of "iDiplomacy" in negotiating media, inherited legacies, and political engagements.

\section{Shifting Demographics, Frames, and Partisanships}

Despite a fastidious trepidation about venturing outside the scope, readers would be better informed by a historical contextualization of immigration, politics, and the ethnic composition of American Muslims. To formulate working hypotheses, researchers rely on accurate tools of measurement, yet persisting imprecisions in survey methodologies have contributed to misunderstanding communal dynamics. For instance, why does polling data estimate such a wide range of the American Muslim population, from as high as 15 million in previous decades, to as low as 3 million adherents in recent years? (Lipka, 2017). For one, religious affiliation is not required on census data, which should suggest that polling is not the best mechanism for knowledge production about a faith community that has been presented as an existential threat and, perhaps, less likely to declare religious affiliation to pollsters. In the mid twentieth century, African (black) American descendants of the TransAtlantic slave trade constituted the majority of Muslims in the country. Black Americans have always been at the center of cultural production; incidentally, when they were the primary "diplomats" for Islam in America, its perception shared an affinity to black protest and counterculture, whereas today, blacks only comprise about $20 \%$ 
of the Muslim population, and Islam is perceived more or less as a foreign religion (Mohamed \& Diamant, 2019).

The story of this rapid demographic dissipation is more than circumstantial; hence, it factors into contextualizing communal power dynamics. An abiding paradox about black Americans is that while they are mostly "Conservative but Not Republican," over 80\% self-identify as Democrats, and no Republican presidential candidate has received more than $13 \%$ of the black vote since 1968 (Philpot, 2017). White and Laird (2020a, b) trace this notable "steadfast partisanship" through the contours of a history that witnesses nearly all blacks supporting the Party of Lincoln after the passage of the $15^{\text {th }}$ Amendment, and then a sudden reorientation toward leftist politics after northern migration and reengagement around issues of organized labor, buttressed by the 1960's Civil Rights movement. At that time, expansion of the welfare state was mostly supported, even seen as necessary governmental beneficence, yet even though the black community has disintegrated as a meaningful polity, blacks have been synonymous to Democrats ever since (Robinson, 2010). However, there is also no shortage of salient arguments from black conservatives pointing to correlations between longstanding public policies and precipitous declines in important metrics regarding black individuals, families, and communities in areas pertaining to crime, education, health, wealth and wedlock, which all suggest Democratic partisanship has fostered attitudinal dependence on the state (Sowell, 2004).

In relation, Malcolm X, an American Muslim cultural icon, made a piercing dichotomy between white liberals as foxes and white conservatives as wolves. Cautioning an audience on December 4, 1963, he noted, "The liberal is more deceitful and hypocritical than conservatives. Both want power; but the white liberal has perfected the art of posing as the Negro's (sic) friend and benefactor". However, among those making competing claims to his legacy nowadays, criticism of the putatively elite liberal order is generally flouted as simplistic unidirectional analysis and ditched in favor of arguments about systemic racism. Surely, negative outcomes persisting in the black community since the 1960s are an indictment of more than solely bipartisan systems, but the debate about agency and individualism versus collectivism and dependence has neither spurred a disassociation nor a reevaluation of black voting allegiances. This is relevant when contextualizing the hundreds of thousands of black Americans converting to Islam since the mid-twentieth century that essentially retained their deep partisan commitments. Conversion to Islam in the USA can be deemed such a subversive and revolutionary act that it is beyond reasonable to expect black converts to successively take on conservative voting positions which would necessitate breaking additional layers of social convention. This point borders awkward essentializing, but such a political expression would realistically make one a twofold social pariah, and as White and Laird (2020a, b) argue, "to the extent that any individual black American values their relationship with other black Americans, they will continue to act in accordance with the group norm of party support lest they find themselves socially isolated".

This limitation of expression gains more complexity when an incoming diaspora of Muslim immigrants voluntarily start arriving on America's shores in great numbers after the 1965 Immigration Act. Professor Sherman Jackson (2005), a black 
convert to Islam, trained theologian, and doyen of black American Muslim studies, chronicles this saga in sequential works. When Jackson opened the Democratic National Convention in 2016 with a prayer, it tacitly signaled that the enduring partisanship was still intact among black Muslim intelligencia. Jackson argues efficaciously, nonetheless, against abiding a priori assumptions essentializing all Muslims as actors primarily motivated by their religion. In reality, tenuous historical anecdotes narrate that immigrants voyaged to the USA in contravention of fatwas issued by clerics in their countries of origin which prohibited immigration to nonMuslim lands for economic purposes. Based on one reading, the story's genesis commences with a first wave of immigration comprised mostly of Arabs and South Asians that naturally did not share the unique racialized social constraint of black partisanship. Regardless of whether or not their religious proclivities were retained, new populations fleeing despotic, corrupt, and war-torn states brought their own post-colonial baggage. For one, they were far less likely to take on critical stances against a regime giving them sanctuary. This diaspora's grit and resilience, however, produced a distinguished number of allopathic doctors, engineers, and entrepreneurial donors, enabling them to build an infrastructure replete with cultural institutions and mosques. Politically, however, the early diaspora's inclination to conformity habitually reflected a spirit of quietist apoliticism, and as such, voting was often shunned or derided as sinful or questionable. A mentality predominated of nostalgically yearning to one day return to the old country and not wanting to make waves inside Pharaoh's house.

However, as perceptions shifted and political participation became viewed as a necessary evil, communities felt compelled to morally assess the two major political parties in order to distinguish the lesser evil. Charles Tripp (2006) documents the twentieth century government-commissioned appropriation of Islamic texts used in attempts to justify numerous failed socialist experiments across the Middle East. Accordingly, the material argument for ostensibly free markets and lower taxes appealed to most immigrants with experiential knowledge or cognizance of recent history. The lay religious assessment also acknowledged that the Prophet Muhammad was, in one capacity, a trader who labored to establish a free market in Medina, and that the five higher objectives of Islamic law (the preservation of one's religion, self/soul, mind, family, and wealth) could appreciably correlate with Republican principles of individual rights, laissez fair trade, religious freedom, and family values. At that time, a predominant diasporic perception was that under such an aegis, albeit imperfect, Muslim communities could generally secure enough justice to substantiate voting for a presumptively upper-class WASP coterie that viewed Islam as an odious yet non-threatening religion. To be sure, the compromise tacitly accepted the flattening of sorts into a constituency. Nevertheless, this pragmatic political calculation of integration over assimilation became a wedge issue with disapproving black Muslims who pointed to a variance between Republican principles and the party's tangible modus operandi. Therefore, diaspora Muslims were seen as evincing a flippant disinterest toward the issue of black suffering and its legacy in the country, whereas black Muslims were shunned by the immigrants for economic laggardness and heterodox religious praxis retained from proto-Islamic groups like the Nation of Islam (NOI) (Jackson, 2009). 
Slowly, media presentations fortified the image of American Islam and its "diplomats" as foreign. In anthropological investigations, black leaders disclose that "news reporters habitually avoid collecting their statements in favor of immigrant Muslim leaders" (2019, p. 62). In addition, diaspora diplomats of immigrant-built institutions often previously expressed sympathies to contemporaneous global Islamist political movements, such as Jamaat-e-Islami, or the Muslim Brotherhood. After September 11,2001 , those ties, no matter how benign in most cases, became endlessly scrutinized as forerunners of the security apparatus, like RAND Corporation, determined that any Islamic espousal challenging the "politics, culture, and economics" of the west was equal to evincing the "hallmarks of fundamentalism" (Benard, 2004, p. 31). Muslims were crudely divided into four categories: fundamentalists, traditionalists, modernists, and progressives, and with all suspected manifestations of Islamism becoming enemy of the state, Islamist power-seeking subtly diffused itself into the platforms of modernists and progressives. RAND Corporation acknowledged that progressives lacked communal legitimacy, and focused instead on cultivating modernists, proclaiming "the modernist vision matches our own." Next, they selectively backed modernists with money, media, and access in part of a robust secularization plan to cull traditional Muslim religious expression (Benard, 2004, p. 37). By the mid-2010s, most American Muslims self-identified as principally committed liberals (Mogahed \& Chouhoud, 2017). Civil liberties of some American Muslims were stripped; acerbic neocon rhetoric spurred a full-blown war on terror, and the security apparatus advanced RAND's "road map" pressuring Muslim scholars to recalibrate their messaging in alignment with the agenda (Rabasa et al., 2007) (Table 1). In a fear-driven and unnegotiated move, votes of the diaspora and their progeny swung to join blacks in their stalwart partisan allegiance, leaving Muslim Republican votes at only $11 \%$ by 2016 (The Economist, 2019). Despite Malcolm X's foreboding about letting the figurative fox in the coop, Muslim American "diplomats" and institutions accepted the newfangled flattened identity designation under intersectionality's rubric of grievances, which complicated their simultaneous claims to his legacy.

The Overton Window has established that consistent advocacy can change any and all political goal posts. Politico notes, "today's fringe theory can become tomorrow's conventional wisdom by the shifting of finely tuned gears that move popular opinion" (Robertson, 2018). Identifying ideological shifts necessitates identifying first principles. The woke era has alarmingly shifted the Overton Window; for instance, Marty Stern acknowledges, "a number of writers on the left and center-left have recently expressed alarm at cancel culture". As a concerned party within the liberal cadre attempting to triangulate the emergence of wokeness beyond its Marxist and postmodernist roots, Stern redirects the blame toward neoliberalism's merge with identity politics when feminists in the fertile soils of nascently constructed fields like Women's Studies seized on obscure French postmodernist thought, which he says helped to create the conditions for cancel culture, Social Justice Warriors, the postmodern Neo-Marxists and the so-called radical left who, some claim, have taken over not only the Democratic Party but mainstream media and the Internet (Stern, 2020). Operating under similar assumptions, Lukianoff and Haidt (2019) attempt to connect the cognitive psychology of woke activism to the anxieties and entitlements of a generation coddled by helicopter parenting that markedly appeared 


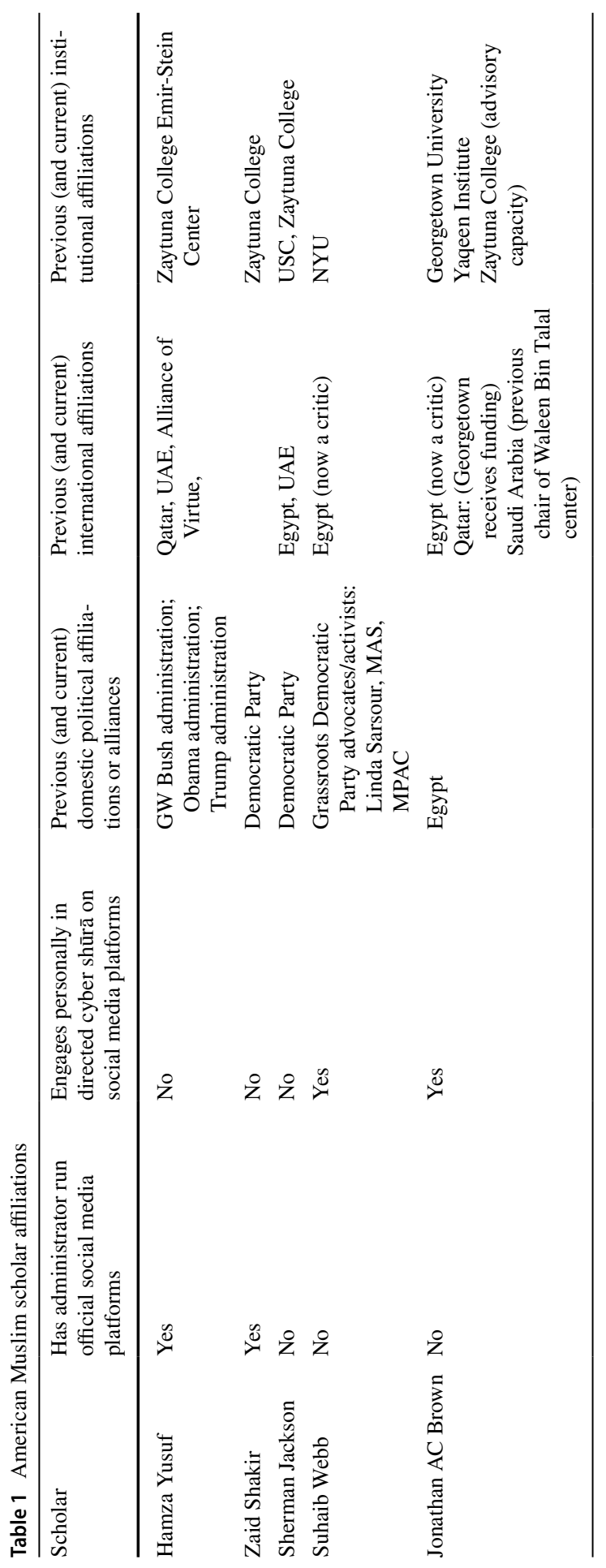


on college campuses demanding safe spaces and trigger warnings in the early $2010 \mathrm{~s}$. However, in their work Cynical Theories: How Activist Scholarship Made Everything about Race, Gender, and Identity-and Why this Harms Everybody (2020), Lindsay and Pluckrose examine the genealogies of maxims like "language is violence" and "science is sexist" in mapping out how illiberal ideas have gone mainstream; they conclude that wokeness is best understood as a religion-like beliefsystem with a concomitant infrastructure that governs the beliefs and practices of adherents.

Therefore, since the societal impacts of wokeness are still in flux and being debated, a sociological view of religion may best elucidate the link to belief and praxis. As Peter Berger explains, "Objectively, the man in the street is confronted with a wide variety of religious and other reality-defining agencies that compete for his allegiance or at least attention, and none of which is in a position to coerce him into allegiance. In other words, the phenomenon called 'pluralism' is a socialstructural correlate of the secularization of consciousness" (2011, p. 127). In all this transience, who speaks for Islam in America today? To use Tom Fletcher's words: who are its diplomats? If traditional religious scholars can still qualify as their communities precipitously secularize, does Berger's point that "secularization has resulted in a widespread collapse of the plausibility of traditional religious definitions of reality" impact the way theologians must communicate, identify, and engage? Arguably, the most notable American Muslim diplomats are scholars from Anglo and black American backgrounds that converted to Islam as young adults, which is remarkable because only about one quarter of Muslim Americans adherents are converts, with $60 \%$ of those identifying as black. However, the dynamics of those from Anglo American descent are harder to triangulate and under-examined because $41 \%$ of American Muslims are listed as "white," whereas in reality, the obfuscating designation on polls includes "those who describe their race as Arab, Middle Eastern, Persian/Iranian or in a variety of other ways" (Pew Research Center, 2017a, b). Certainly, some identify with "whiteness" in implicit adulation of dominant culture; in such cases, the perceived whiteness of a scholar could factor into demographic reception contrarily to a woke demographic that is more likely to deride Anglo or European heritage as "privilege." Both views can problematically discount merit; similarly, iniquitous licenses are extended to scholars based on their "blackness" or other class and ethnic markers. Thus, the convert scholars carefully selected for closer analysis in this study intentionally represent these dissimilar cultural stratum and political outlooks.

\section{Data and Methodology}

This study examines American Muslim dynamics between 2016 and early 2021, a period extraordinarily informed by Donald J. Trump's presidency, media weaponization, contemporaneous geopolitical feuds in the Middle East, and global lockdowns attributed to COVID-19. In consideration of these contexts, it was necessary to adopt an interdisciplinary model that did not encumber the incorporation of situational awareness. Similar to the Overton window, Daniel Hallin (1986) separates 
the public opinion corridor into three spheres. In the consensus sphere, which is susceptible to becoming a false-consensus, people are given liberty to invoke shared assumptions. In the sphere of legitimate controversy, people can still wade in on controversy, but with more evinced caution. Conversely, for ideas sequestered into the sphere of deviance, people are censored and cancelled. The woke era has shifted much conservative and traditional content into the sphere of deviance. But this cannot be assessed and observed unless the right typologies are selected. Under the wide umbrella of the Sunni super-tradition, researchers often categorize adherents by groupings, but American Muslims have arguably transcended the use cases of most academic typologies. The label neotraditional has been used to describe a strand of Islamic thought in contradistinction to Salafism (Shepard, 1987). For instance, Barzegar (2011) uses the fraught term in an attempt to move away from lazy sectarian demarcations and ethnic distinctions in favor of a discourse-centered approach, noting the distinction in its pushback against many of the assumptions of modernity and pursuit of reviving participation in traditional Islamic sciences, inclusive of legal schools and the inward orientation of Islam referred to as Sufism (tassawuf). In this way, Newlon (2017) posits that neotraditional American Muslims are a distinct and clearly defined community.

Hamza Yusuf Hanson, born Mark Hanson in 1958 and raised in Marin County, California, has been one of the most publicly recognizable scholars linked to the neotraditional label. A convert from a Greek-Irish American background, Yusuf focuses on engagement with elite Anglo American conservatives in the USA on issues like abortion and religious freedom. Simultaneously, he has long-maintaining advisory posts in the United Arab Emirates (UAE), a country where he studied in the 1980s. In contrast, Suhaib Webb focuses on engagement with youth and communities that lean left. Webb is known as "The Snapchat Imam" for his prolific use of social media where hundreds of thousands of liberal Generation Y and Z Muslims access and engage him (AJ+, 2016). But in the age of wokeness, goal posts have shifted; therefore, the political spectrum is no longer a useful framework with its vestiges inherited from a French king positioned on the right side of a parliament opposite his liberal nemeses. Consequently, in contrasting Webb's approach to Yusuf's, it is imperative to avoid the bludgeoning comparisons that flatten Muslims into caricatures within the progressive versus conservative binary even if one could argue these to be their respective leanings. At first glance, certainly both scholars are male, Anglo American converts similarly trained in the same (Maliki) legal school who have endured against stereotypes. Yet, while these similarities are not negligible, they do not situate the crux of the scholars' variant approaches, some of which are generational, and others rooted in praxis. These two scholars take dissimilar approaches to engaging wokeness. While Webb discernably juxtaposes Yusuf on issues like social media engagement, politics, and pedagogy, their point of departure becomes discernable within a wider emic event that ties in domestic partisanship, identity politics, and geopolitics as American Muslims renegotiate the ontology of the black American Muslim legacy.

Selecting Yusuf and Webb for closer analysis, it was necessary to monitor their engagements, social media platforms, and related comments sections. In addition, it was necessary to analyze the themes of their sermons and lectures, and to read 
Yusuf's extant publications as well as several publications penned by Yusuf's longtime teacher, Sheikh Abdullah bin Bayyah, a renowned scholar of jurisprudence and its philosophy with a long history of political engagement. Subsequently, it was necessary to compare and contrast these thematic ideas with over 100 op-eds published between 2016 and 2020 within a growing body of literature critiquing Yusuf and Bin Bayyah's political engagements. From these, I selected a demonstrative article to tie in the emic themes and figures under examination. For in-person observations, I attended a series of events Yusuf, Bin Bayyah, and Webb were scheduled to appear at across North America and the Middle East. Attendance at retreats, conferences, and lectures across global sites requires access, funding, a nuanced understanding of community dynamics, and often foreign language competencies. All site visits were conducted between 2016 and 2019, whereas throughout 2020 and early 2021, I continued to monitor events digitally. Situating these cyber contestations within their larger contexts necessitates nuanced considerations of Islamic theology and jurisprudence, media theories, and geopolitics. While the limitations to being a bodied researcher are known, facing few of the standard impediments enabled me to analyze exchanges, interpret audience dynamics, and overcome contextual gaps in the research about American Muslim scholars, their audiences, and respective political outlooks and digital cultures. After attending events, I created transcripts of unstructured interview discussions and developed in-person ethnographic vignettes, translating into English when necessary. While carefully crafted, this methodology has shortcomings in its descriptive nature, yet its appropriateness is due to preexisting literature not sufficiently establishing the dynamics of these audiences.

\section{Hamza Yusuf: Bound to Time-Binding Media}

Inextricably, Hamza Yusuf's public perception is defined by erudition and book smarts. Over five decades ago, communications scholar James Carey (1967, p. 22) summarized and contrasted the views of his predecessors Harold Innis and Marshall McLuhan in a classic paper précising the latter's well-known thesis, which generally claims that communication media's technological forms have a bigger impact themselves as mediums than the content they disseminate, or that the medium is the message. We think here of the book. Although it has a limited reach, the text creates a different way of thinking for a literate class that spends time in solitude and reflection. Accordingly, raised as the scion of a notable family in Marin County, Yusuf is an inveterate reader whose primary culture is an extension of the western canon's great books tradition. His father was a scholar of Elizabethan texts, and it was impressed upon Yusuf that virtues and aesthetics had real import, and that some texts were foundational and worth committing one's life to. Such a world privileges one to access tradition and invites one to become time-bound to timebinding media that affirms eternal verities: truth, hierarchies, and certain beliefs about human nature. Hence, when Yusuf converted to Islam at 17 and traveled to the Muslim world, immersing himself in Arabic, the liberal arts, the tradition, and the reading and memorizing of religious texts and poems, he naturally excelled as someone culturally attenuated to that type of medium. Surely, he brought with him the 
appreciation for his own preferred poets, Dylan, Yates, and Shelly, but one quickly discovers that Antara, Imru al-Qays, and Al-Shafi'i are working with the same rhetorical tools.

Speech emphasizes tradition and focuses on the past, but as a slow-moving medium, it requires a speaker to travel widely to be impactful with it. Fortuitously, Yusuf returned to the USA during the dawn of the first-ever epoch in which Muslim scholars rapidly shuttled around on planes to give speeches, and he instantaneously became a celebrity on the nascent Muslim-speaking circuit in the 1990s across North America and England. Elucidating his theory further, James (1967) explains that "Modes of communication, including speech, are, then, devices for fixing perception and organizing experience". Correspondingly, in fiery rhetorical presentations, Yusuf drew on the five canons of the rhetorical tradition to mediate his experiences from abroad, and for a certain demographic of Muslims, he became the medium by which hundreds of thousands - maybe millions - fixed and organized their perceptions of Islam. In Yusuf's totalizing presentations, Islam could not be reduced to simply a religion or a political ideology; it was repositioned as simultaneously a salvific creed, a way of being, a worldview and aesthetic that was in conversation with the world's great traditions as the inheritor of the Peripatetic school and civilizational conduit that gave birth to western civilization. These inventive presentations took the English-speaking Muslim community by storm. None had as seamlessly weaved the western classics into sermons on the Quran. A Saudi-based television show chronicled his global travels and interactions for two seasons, widening his reach. Yusuf sustained this efficacious influence through the era of cassette tapes, and then into the era of compact discs, DVDs, mp3s, and television that preceded the era of social media.

\section{Suhaib Webb: Bound to Space-Binding Media}

Born in 1972 and raised in Oklahoma, William Webb flouted the advantages accessible to him as the son of an Anglo American history professor, and instead rebelled as a teen, running with the Piru Bloods street gang, immersing himself into rap culture, and DJing. Later, through serendipitous events, he converted to Islam, took the name Suhaib, memorized the Quran, trained to become an imam, and eventually graduated from Al Azhar University's prestigious seminary in Egypt. During different phases, Webb has been loosely affiliated to various ascriptions, blogging publicly about a "departure" from traditionalism in 2007 (Abu-Reem, 2007). Accordingly, media framings of Webb often reflect the reductionist framing of the security apparatus. For instance, The Boston Globe concedes that it was iniquitous for Charles Jacobs of the Jewish Advocate to misleadingly link Webb to the Muslim Brotherhood and extremism, but adding insult to injury, the RAND Corporation's endorsement of Webb as an exemplar "moderate" is cited as if such exoneration is desirable (Wangsness, 2013).

Consequentially, Webb actively works to create his own narrative. In the 2000s, Webb permitted budding journalist Ben Hubbard to shadow him across the country at speaking engagements. Now an acclaimed author and Middle East correspondent 
for the New York Times, Hubbard's investigations into Anglo American imams have segued into criticism of Arab regimes, making him the target of espionage via Israeli spy technology, which is a reminder of the risks associated with opining publicly on religion and geopolitics (Kirchgaessner, 2020). Similarly, Webb and Yusuf were both placed on a public kill-list by the terrorist group ISIL, although Webb downplays the threat, telling a journalist that he is more concerned about intimidations from the "far-right" (AJ+, 2016). Part of Webb's rare crossover appeal is precisely this ability to slip in and out of woke diction, an impact magnified by his itinerancy. Still often accompanied by shadows, Webb makes his appearance schedule public. Therefore, in June of 2017, at the Islamic Center of Irvine in Southern California, I am able to sit with a group of Muslim teens on the floor and observe how Webb shares his experiences about smoking marijuana and praying on the bathroom floor of a nightclub, a powerful discourse model that immediately lowers the teens' defenses. Later, outside of the mosque, teens play basketball and approach him one by one to seek counsel on a range of issues. His ride arrives-likely an Uber-and whisks him off to speak at another venue, yet I witness this pattern again days later at a Persian restaurant, and again at another mosque in Orange County. Each time, youth and parents verbalize their appreciation for his efforts at remaining accessible through social media where he reputedly responds to answers within 24 hours. To test the claim, I send a question related to jurisprudence and receive his response within the timeframe.

These little snapshots speak to an emphasis on accessibility despite transiently moving between different institutions over the last two decades, from California, to Massachusetts, to Washington DC, and New York. Back in 2009, Webb's blog received the Brass Crescent Award for blog-of-the-year. Since that time, his media engagement has become prolific. Webb's primary culture is evidently the hip-hop culture of the 1990s; therefore, he naturally code-switches from Arabic into an urban English register with poetic diction on 8-s Snapwas (Snapchat-fatwas), TikTok posts, and lectures delivered via Instagram that cumulatively reach hundreds of thousands of followers. In an interview with $A J+$, Webb describes Snapchat in religious terms, while sporting a Boston Red Sox cap: "This is the language of today, the Prophet Muhammad was given the Qur'an because poetry was kind of what was popping' in the Arabian hood, so this is the way that we communicate now". Carey (1970) argues that space-binding media are ephemeral and meant to reach as many people as possible over long distances, but that they tend to facilitate rapid change, materialism, and secularism. By analogy, digital media falls under this classification because they shift the special boundaries between work life and home life, restructuring our time. Webb tells Quartz (Khan, 2016) he was initially reticent about joining social media, "You get on Snapchat for two reasons: one is to reach a demographic of $13-23 \ldots$ secondly, is to learn the language of the youth". Studies find that when American Muslim youth are triggered, they go online before mobilizing in-person. The decision was based on data, such as one report that suggests, "American Muslim responses to triggers signal important model-changing dynamics-new media allow activists to work around hierarchical processes that may retard or block grassroots mobilization" (Sheresthova, 2016, p. 163). Therefore, a fair appellation to ascribe to Webb is street smart because in sensing that youth are inclined to bypass 
traditional organizational structures and religious figures, he meets them where they are.

\section{An Emic Contestation of Legacies and Leadership}

On June 3, 2016 the legendary boxer and Muslim icon Muhammad Ali passed away. The public funeral was slated to span across 2 days of nationally televised service: day 1 for Muslim services, and day 2 for general eulogies given by politicians and the general public. Prior to his passing, Ali had selected Imam Zaid Shakir as a spiritual advisor. Ali decided years in advance that Shakir would deliver the eulogy and coordinate the funeral arrangements with Dr. Timothy Gionatti whose primary goal was to make decisions "true to Ali's life and legacy and vision, while remaining absolutely faithful to Islamic traditions" (CBC, 2016). Shakir is a convert of black, Irish and Native American descent with a background in political science who comes out of black civil protest movements. For context, there is not much a bigger endorsement than being named the "people's Imam" by the "people's champ" in the American Muslim landscape. Shakir is also noted for co-founding Zaytuna College in 2009 with Yusuf and Professor Hatem Bazian. While the liberal arts college is oft-linked to the neotraditional label, closer examination reveals more complexity. For one, the college is heavily impacted by the political environment of Berkeley itself, which rivals the curriculum's impression on its students; moreover, the engagement approaches of its founders are sometimes at variance.

Prior to 2016, Yusuf and Shakir had held shared yearly intensive study retreats in Turkey where their relationship to the government remained amicable. However, the bond was visibly strained when Turkey's leader, Recep Tayyip Erdoğan, made a request to "join the ranks of eulogists" and was denied (Junod, 2017). Muslims from all over the world descended on Louisville, Kentucky, for the burial June 9, 2016. Scholars from different backdrops like Yahya Rhodus, Yasir Qadhi, and Omar Suleiman all joined together in the descending single-file prayer rows. Standing feet away from pallbearers in front-which included Jackson and Yusuf - an insistent Erdoğan and his security detail were positioned just behind the police line holding a black cloth from the Kaaba (kiswa), which Erdoğan wanted to lay onto Ali's coffin as a symbolic gesture. However, with the threat of a sacred event merging into a political public relations event, the organizers maintained their refusal. It was a pivotal moment that triggered a shift in political trajectories and the end of Yusuf and Shakir holding their retreats in Turkey. Only a few short weeks later, the July 15, 2016, coup d'état attempt (15 Temmuz darbe girişimi) took place. Disputed allegations pointed to coordination with Fethullah Gülen, a faith leader based in the USA that RAND Corporation had promoted as an ideal modernist promoting "nonviolence" (Benard, 2004, p. 38). The coup attempt provided Turkey license to purge adversaries across institutions, which western media was highly critical of. However, it was not until 2018 when a street in Ankara was renamed "Malcolm X Avenue" that commentators 
began acknowledging the abundance of soft power that black American Muslim icons and their legacies hold (Adar \& Yenigün, 2019).

Recently, the proposed inheritors of these iconic black American Muslim legacies have been contested on social media by writers embodying the 2 nd and 3 rd generation diaspora's adoption of woke frames and critical race theory. An online kerfuffle in 2019 demonstrated how a singular emic event can tie in numerous threads of contested intercommunal history. It starts with an Al Jazeera op-ed by Ali Al-Arian (2019). The author claims that Islam in America was once "a political identity grounded in an ethos of dissent, exemplified by Muhammad Ali and Malcolm X" but that today, the legacy's inheritors "lack political courage and moral integrity". The article makes an explicit indictment of Yusuf and Jackson for "dubious interactions with state power" and lending credibility to "white supremacy and tyranny" which includes criticizism of Shakir, for shielding their actions; it then disparages the entire Muslim community as thoroughly compromised and includes "every pillar - the intellectuals, the spiritual leaders, the political organisers, the schools, the mosques, [and] the civil service organisations". This initially obscure author's piece went viral in many Muslim circles because despite its mix of imprecisions and ad hominem arguments, it raised legitimate questions that had been on the minds of the wider audience which the scholars had not sufficiently addressed in the public square. Neither Malcolm X nor Muhammad Ali shared the vision of political Islamists, and some of the claims were so controversial that it spurred many to wonder aloud if the woke Muslim impulse had taken things too far. One such Tweet came from religious freedom advocate, Ismail Royer, asking "Who will we cancel next?" (Royer, 2019). Another Tweet from professor Salman Younas (2019) noted, "Imagine how irrational your discourse on 'resistance' must be when people like Imam Zaid \& Dr. Jackson become supporters of white supremacy to you \& sell-outs".

The op-ed provoked both Shakir and Jackson into exigently responding. As a selfproclaimed technophobe with no social media presence, Jackson (2019) responded with a scathing rebuttal that was posted on the blogsite of his institute. It circulated widely despite having no concomitant forum for communal interaction. In the piece, Jackson accuses Al-Arian of textbook demagoguery:

He and those who make up this alleged consensus are apparently offended by Trump's so-called Muslim ban. But a Blackamerican sister in Chicago once asked me rhetorically why she should support having Muslims come to this country who are only going to treat her like crap. We heard this same talk about Muslim consensus leading up to the 2000 presidential election, i.e., that the Muslim community was united behind George W. Bush ("family values" and all). But is there anyone dauntless enough to suggest that the Blackamerican Muslim community unanimously supported Bush? These are the kinds of false consensuses that we have been dealing with for years. And al-Arian sees fit to base his indictment of Muslim leaders on such flimsy grounds?

Amidst widening fragmentation, communal claims of consensus are contested by competing historical narratives. Al-Arian partially predicates his arguments on conceptualizing Islam as a revolutionary movement grounded in dissent; therefore, 
the implicit supposition is that particular political stances are analogous to communal religious consensuses, and in this case, a stand against Executive Order 13,769, dubbed by him and others as the Muslim ban. While there was some vocal resistance to the ban, immigration is not a consensus issue among Muslims (Pew Research Center, 2018). And, operating outside of the academy's confines, Jackson is able to explain this by pastiching the raw sentiments of a black female archetype asking a visceral hypothetical about why this issue should even be a concern for black Americans. In addition, Jackson and Shakir both deem it not insignificant that the author's father is professor Sami Al-Arian, the Palestinian activist credited with swinging the Arab and Indo-Pak immigrant Muslim vote in Florida to help seal the electoral victory of George W. Bush in 2000 (Leiby, 2002). Once Bush was in office, however, politically motivated aspersions were cast on the senior Al-Arian, and after prosecution and plea bargaining, he was deported to Turkey, a familial connection that adds multiple layers of complexity to the emic event, and contextualizes the author's explicable discontent. Shakir (2019), who also responded to Al-Arian, posted his reply onto his official administrator-run Facebook page, where there are about one million followers. One of Shakir's point-by-point responses demonstrates just how widely competing intercommunal narratives of the past now diverge on consensus-building:

The Florida Muslim voting bloc, after Bush's narrow victory, boasted that they were the "kingmakers." It is strange that those family values, which included anti-abortion and anti-gay marriage stances, are the same ones that Shaykh Hamza Yusuf is being condemned today for trying to defend. What has changed? Certainly not Islamic teachings around those values.

Shakir responds from the sequential view that after the 2003 Iraq invasion, a near consensus emerged among Muslims that helping to elect the neoconservative project was a mistake because it subsequently ushered in the Patriot Act and destabilization of the Middle East.

\section{Partisan Fitnah and Weaponized Journalism}

Malcolm X called media "the most powerful entity on earth" for its ability to "control the minds of the masses," and media weaponization is an identifiable culprit for the stratification of society into polarized filter bubbles, including the disparate audiences now making claims to his legacy and those of other black American Muslim icons. The genesis of changing mediascapes traces back to numerous factors and historical events. But it would be remiss not to mention the fairness doctrine, introduced in 1949 by the Federal Communications Commission (FCC) requiring media to present controversy in a manner that was honest, equitable, and balanced; the FCC eliminated the fairness doctrine in 1987. Similarly, passing the Telecommunications Act of 1996 allowed effective monopolies to gain tight control over information in the media while avoiding the enforcement of antitrust laws. Thereafter, a rapid consolidation of over fifty companies folded into the hands of what is now only five: Comcast, Disney, AT\&T, National Amusements, and News Corp, all of whom are 
corporate members of the Council on Foreign Relations and therefore not decoupled from the press-agentry propaganda model Edward Bernays advocated (Lutz, 2012).

Recently, there have been concerned investigations into the dangers of the dwindling opinion-diversity in mainstream reporting. For example, Investor's Business Daily is concerned with leftist biases, noting "Despite journalists' denials, it's now pretty much a fact that journalism is one of the most left-wing of all professions" (2018). While wokeness is a phenomenon on the left, the trend of catering to partisan interests in a divisive manner, simply to boost ratings, also circles back to the phenomenon of Fox News emerging under the direction of Roger Ales and Rupert Murdoch's News Corp (before Disney bought it in 2019). MSNBC and other networks speedily followed the one-sided model, which has created radicalizing partisan echo-chambers. Matt Taibbi makes the point that "neither side is journalism" (2019, p. 16). Through the remorseful commentaries of rare dissidents like Taibbi, the curtain can be pulled back a bit, however. In his self-styled gonzo-fashion taking inspiration from Noam Chomsky's theory of manufactured consent, Taibbi acknowledges the "undeniable gravitational pull toward the Red v. Blue narrative" that he struggles with as a "Blue" despite being cognizant that "partisan politics is a bit of a con" that sews discord.

Coinciding with the years of this research, the political career of Donald $\mathrm{J}$. Trump heralded in a new era of ideological media coverage that exposed biases and impacted the subjects and environments being analyzed in ways unprecedented. One of Taibbi's germinal concessions is that within the "liberal media," he and his colleagues "started to employ anti-intellectualism" to deal with Trump (p. 15):

In 2016 especially, news reporters began to consciously divide and radicalize audiences. The cover was that we were merely 'calling out' our divisive new president, Donald Trump. But from where I sat, the press was now working in collaboration with Trump, acting in his simplistic mirror image, creating a caricatured oppositional demographic and feeding it content. As Trump rode to the White House, we rode to massive profits. The only losers were the American people, who were now more steeped in hate than ever.

The paradox is that Trump benefited from an estimated $\$ 2$ billion of free media coverage in his 2016 run for the presidency, but then in his first 100 days in office, a swift repositioning set a "new standard for negativity" in reporting at around $80 \%$ according to a Harvard Kennedy School report, with negative coverage at outlets like the Jeff Bezos-owned Washington Post reaching 24 to 1 and higher throughout the term (Patterson, 2017). The pivot into wokeness and weaponized media is a confluence preeminently narrated by Glenn Greenwald, well-reputed for risking his own life to break the Edward Snowden story about National Security Agency spying. Greenwald, who identifies with the center-left journalistic ethos of the 1990s and 2000s that checked power, condemned censorship, and championed free speech evaluates the current environment as illiberal, pro-censorship, and obsequious to "militarism, imperialism, and corporatism" (2021). In the aftermath of the 2020 election, but critically prior to the January 6, 2021 spectacle in Washington, Greenwald colorfully reflects on the overall media coverage of the Trump presidency in retrospective language: 
There's no question it's gotten radically unhinged and way off the deep end in the last four years $\{2016-2020\}$ and it's not hard to understand why... If you convince yourself that the President is an actual despot, that he's a tyrant, that he's a dictator, that he poses an existential threat to democracy, that he's even like a Hitler like figure; that he commands this white supremacist, terrorist ring; that he gives orders to the Proud Boys that is this formidable insurrectionary fascist organization as opposed to a bunch of fringe obese losers role-playing... If you convince yourself of that - which they have - then it becomes justified to do anything in the name of stopping the President. Getting the military to step over their boundaries, lying in order to undermine the President, concealing information that might help him, publishing false information that would weaken him. I mean if you're really facing Hitler, then all the rules of the game change.

To be sure, Greenwald (2020) acknowledging that Trump operated under a "deep state coup" does not correspond fallaciously into an exoneration of Trump's own obvious mishandlings, including his infamous trolling. When intelligence agencies leaked disinformation painting him as a Kremlin agent, Trump injudiciously took the bait and trolled the intelligence apparatus on Twitter for gaffes like the Iraq war prior to his inauguration in 2017 (Gittens \& Dilanian, 2017). Chuck Schumer remarked to Rachel Maddow, "You take on the intelligence community; they have six ways from Sunday to get back at you. So, even for a practical, supposedly hardnosed business man, he's being really dumb to do this" (Schumer, 2017). Taibbi (p. 472) labels Maddow one of the worst "professional partisans" for peddling the Russia conspiracy theory that catapulted her into the number one cable news slot in the country, eclipsing 3 million viewers.

Nevertheless, at the risk of becoming a pariah, few in the weaponized media environment dissented. But toward the end of the term, distinguished acknowledgements surfaced. Right before her departure from the New York Times, for instance, Bari Weiss tried to explain to woke audiences that "Joe Rogan Is the New Mainstream Media"; the title signified that people were ditching propaganda in favor of alternative media voices and podcasters "more influential than the entire slate of hosts on CNN" (Weiss, 2020a). Upon leaving the paper, Weiss confirmed categorically that "woke Twitter" was the ultimate editor: "a new consensus has emerged in the press, but perhaps especially at this paper: that truth isn't a process of collective discovery, but an orthodoxy already known to an enlightened few whose job is it inform everyone else" (Weiss, 2020b). Before leaving his own organization, The Intercept, for similar partisan intervention that suppressed his reports tying Joe Biden and his family to corruption, Greenwald (2020) also tried to explain how the backlash against Rogan's \$100-million contract with Spotify signified alternative media's displacement of top-rated cable news programs.

During this entire period, however, mainstream American Muslim discourses stayed heavily in-sync with the left's mainstream media filter bubble, displaying an aversion to data points appearing at all conciliatory to objective evaluations of Trump, Republicans, independents, or those on the left dissenting against cancel culture. These attitudinal positions are contextualized by research showing that 
communities feeling victimized take comfort in systems seeming to offer them protection. For instance, when polled in 2017, 68\% of American Muslims said Trump made them feel "worried," and $75 \%$ believed there was "a lot of discrimination" against Muslims in the USA (Pew Research Center, 2017a, b). However, by the time the 2020 American Muslim Poll was released, it reflected these sentiments notably taking a concerned look at "Muslim and general public Americans who prefer Trump" using regression analysis to understand why his approval ratings continued to rise in the community, from $13 \%$ in 2018 , to $15 \%$ in 2019 , to $30 \%$ in 2020.

There was no indication of discernment that weaponized journalism and Silicon Valley tech companies were setting dangerous precedents by censoring dissent, including a sitting president, as part of a greater purge in official American Muslim spaces. Because to be publicly perceived as giving Trump or his administration even a single concession fell within "the sphere of deviance" (Latif, 2019). This had organizational impacts on those claiming to authoritatively represent Muslims in the USA. For example, the Council for American-Islamic Relations (CAIR) publicized themselves from 2016 to 2020 as foremost anti-Trump Democratic blocs securing the ostensibly consensus "Muslim vote." But these consensus assumptions were challenged when Muslims were polled and only $51 \%$ would affirm their Democratic support, with a large number remaining undecided. Despite this wide contrast, institutions like CAIR and many other "diplomats" carried on with the woke anti-Trump message as if it was a de facto binding religious consensus issue; the hyper-partisanship did not abate or even recalculate after the Biden administration reaffirmed there would be "no role" for pro-Palestinian activism, which it labeled "anti-Semitic" (Blitzer, 2020). Despite the mounting cognitive dissonance, Shakir and many others made urgent pleas for American Muslims to vote for Joe Biden and the Democrats in the fall of 2020, leaving some to question whether the unhesitating partisanship of black American and diasporic Muslims had merged into another false-consensus in need of reevaluation.

\section{International Fitnah: Politics and Weaponized Arab Media}

In this emic cycle, Hatem Bazian's founding role at Zaytuna College is demonstrative of how fitna in American Muslim contestations is inseparable from Middle Eastern politics. Bazian's politics are far-left and progressive, and as a Palestinian activist promoting the Boycott Divest and Sanction (BDS) movement against Israel, he is considered a nemesis at visceral odds with the agendas of Arab states normalizing Israeli relations. This overlap in interests demonstrates the complexities in communal political expression. Similarly, while Shakir may share partisan expressions with his critics on the left, he differentiates his positionality in labeling Al-Arian's interpretation of communal chronology as "selective outrage" and a "colonized reading" because it seeks no valid redress to religious scripture:

His intellectual frame of reference is simply informed by a different set of "dead white men" than that of those he condemns. The ideas of Marx, Lenin, 
Habermas, Horkheimer, Adorno, Gramsci, Sartre, Marcuse, Foucault, etc. undergird his analysis while any reference to the Qur'an, Sunna (Prophetic traditions) or the interpretations of Muslim scholars is tellingly absent.

In acknowledging that political Islamism has resituated itself within secular pathways to power by using the woke discourses of intersectionality and critical race theory, Shakir also contends that these premises contain inconsistencies, quipping, "It is curious that Al-Arian himself has not found the moral integrity or political courage to condemn the government of Qatar for the role it directly plays in facilitating the policies he condemns others for indirectly supporting". Qatar has been accused of sympathizing with certain Islamist projects while simultaneously housing United States Central Command (CENTCOM), a controversial platform and launch point of attacks that have killed civilians (U.S. Department of Defense, 2016). Between 2017 and 2021, when Qatar and the UAE became openly embroiled in regional political disputes, Qatari state-funded Al Jazeera published numerous critical pieces against states and actors it deemed adversaries. Since the 1980s, Yusuf has maintained ties with the UAE government; similarly, Jackson keeps ties to both the UAE and Egypt, where he studied; as a result, they have both been targeted by incendiary pieces with provocative titles like Hamza Yusuf is not your friend (Hamad, 2019), and It's time for Muslim Americans to condemn Hamza Yusuf (Hilal, 2019). While Yusuf's ardent supporters may dismiss these critical pieces altogether, wider reactions indicate that most community members want religious leaders to publicly address their political and funding links, and to explain how the harms of these associations are outweighed by any potential benefits.

Back in 2001, Yusuf was dubbed by journalists as the most influential Muslim scholar in the west because of his unparalleled impact on Islamic thought and practice in anglophone contexts (O'Sullivan, 2001). However, today, not only is he criticized for his politics, but he is intentionally absent on social media, confessing to tweeting once and instantly regretting it. Therefore, as criticism of his engagements has become widespread, it has also become difficult to discern his rationale sans his participation in a neutrally arbitered public forum. His particular traditionalist perspective is suspicious of the first principles of modernity and its sine non qua, democracy, for its inherent susceptibility to capture by corporations and plebeians alike, which partially explains his preference for monarchies as ostensibly stabilizing forces. However, despite precedents for this opinion found in the sagacious writings of medieval Muslim theologians in the premodern period, modern audiences informed by liberal norms find aspects of Yusuf's traditionalism unpalatable. These voices criticize modern monarchic nation-states primarily for their autocracy and violent foreign policies. However, another way of looking at it is that the partisan assumptions often undergirding such criticisms also tacitly necessitate overlooking the even greater foreign policy blemishes of the US empire, as well as solid evidence that the empire has been captured by an oligarchy (Gilens \& Page, 2014). 


\section{Perspectives from the UAE: Online and Offline Divergence}

After observing the first three iterations of Abu Dhabi's Forum for Promoting Peace in Muslim Societies online, in December 2017, I attended in person. Despite widespread cognizance that the UAE capitalizes on the public relations effects of the conference, people offer their own rationales for attending and engaging. Therefore, I conduct unstructured interviews with several faith leaders. In the lobby of the St. Regis hotel, congregating with a group of black American Muslim leaders, including Ubaydallah Evans and Aisha Adawiya, Jackson states that his physical attendance at the conference recurringly hinges on the verbal guarantee that he will be allocated time to freely deliver addresses that communicate the concerns of his conscience and the prerogatives of his imagined community. Furthermore, Pastor Bob Roberts offers the perspective of conservative American Evangelicals who anxiously desire to symmetrically secure more rights for Christian minorities in Muslim-majority states. Additionally, Rabbi M. Bruce Lustig, Washington Hebrew Congregation's Senior Rabbi, expresses his desire for the reduction of violence against religious minorities. While these desires are valid, at the same time, the sheer tone and presence of known proponents of Israel, including various think tank personnel, makes it discernable that a détente, later made public in 2020, is forthcoming. Meanwhile, as the conference is in session, condemnations appear in the form of op-ed publications and social media posts of prominent American Muslims. Nonetheless, there is no specific mention of these concerns during any of the panel sessions; therefore, the offline and online contexts appear divergent.

As the barrage of attendees, leaders, and media people have come and gone, I stand in the lobby amongst a group of people speaking with Yusuf about a range of issues, including his reasons for politically engaging. Despite being a reputed scholar in his own right, in a very traditionalist manner, Yusuf appears to defer to Shaykh Abdullah bin Bayyah's decisions on political engagement. One of Bin Bayyah's maxims about engagement is: an empty chair is not a strategy. It assumes that if theologians are not interfacing with governments, bad actors will fill the void. However, if this maxim is applied to the new digital square, it is an open question if Yusuf's digital presence is considered an empty chair or not. Historically, the proximity of public intellectuals and theologians to statecraft has always been tenuous, and Yusuf's approach to engagement has been heavily criticized. Bin Bayyah encouraged Yusuf's meeting with president George W. Bush after 9/11, which subsequently tarnished Yusuf's reputation. Moreover, Yusuf's engagement with the UAE, Qatar's off and on nemesis, has attracted attention from Al Jazeera, which has documented editorial sympathies with the Muslim Brotherhood and affiliates (Lynch, 2006). According to Samuel Tadros (2014), who hails from the tight-knit Coptic Egyptian community, "the Brotherhood focused on building an English language media arm, one that would not appear to be controlled by it directly", and in a report, Tadros (2015) names both the Middle East Monitor and Middle East Eye as two of those alleged affiliates. In addition, there are several academics who have oriented their research profiles toward critiquing Yusuf and his network almost 
exclusively, leaving no short supply of analyses such as Al-Azami's (2018) piece, UAE's forum for "promoting peace" is another cynical PR initiative'.

The Arab media's weaponization is used to advance specific state interests, which differs slightly from the US media's capture by corporate ideological agendas. At their disposal, the UAE has The National and Saudi Arabia has Arab News, English language outlets with a wide reach. Zooming in closer to the emic event, however, it may not be insignificant that Ali Al-Arian's sister is Laila Al-Arian, a journalist for the Al Jazeera Media Network and wife of Georgetown University professor Jonathan A.C. Brown. A conscientious critic of many parties, including the Muslim Brotherhood, Brown is another convert from Anglo American heritage on the receiving end of censure. His critics cite things like Brown presiding over posts with direct and indirect academic funding ties to Saudi Arabia and Qatar, as well as his ties to Zaytuna College in an advisory capacity. However, quite accessible and transparent, Brown regularly joins podcast discussions and hosts robust debates on his personal Facebook page, which has its profile image set as the Rabaa resistance image, a clear sign of protest against Sisi's regime in Egypt. Brown wades into political debates, but is open about his caveat that he cannot criticize Turkey because it has given his father in-law safe refuge.

After physically attending a previous iteration of the UAE conference, Brown penned a piece titled The Problem with the UAE Summit (2018) that censors the UAE and its foreign policy, noting that while Yusuf's speech there was "conscientious," it was only a small divergence from a "clear message" that to contest government is to "invite chaos." It is a fine line between accepting funding from autocratic governments or coopting forces and maintaining objective criticism. This is demonstrated by Brown's reaction to Ali Al-Arian's op-ed, which criticizes Zaytuna College's acceptance of funding from the John Templeton Foundation for its sympathies with Tea Party Republicans and unpopular "counter-extremist" groups like the UK-based Quilliam Foundation. Brown's (2019) first post after the article surfaced contains in it a subtle opprobrium in its stating, "We should be accurate and intelligent in our criticism of organizations". Acknowledging that the foundation's current funding cycles award grants exclusively to neotraditional projects that Brown himself would not likely qualify for, previous cycles have funded a wide range of pursuits, including Muslim research in Qatar. Therefore, the pragmatic view seems to evince a cognizance that institutions, especially think-tanks, work on multiple levels; tokens or native informants who desired recipients ingratiate themselves with are leveraged in different ways, and then recycled, necessitating an "intelligent" approach to monitoring ideological and personnel phases, and revelations about the aims of funding decisions.

\section{More Than Skin Deep: Splinters Begin to Show Publicly}

Despite their differences, Webb's ascent as a scholar did not initially undermine public cordiality with Yusuf, who is more than 15 years his senior. In 2011, Webb gave a speech at Zaytuna College asking God to bless the founders (Webb, 2011). In 2014, CNN covered Webb's sermon responding to anti-Islam attacks made by 
Bill Maher and Sam Harris in which Webb explicitly promotes Yusuf as a figure the community should authorize, "We can differ with Sheikh Hamza on a number of issues but the khair (goodness) is much more, the good is much more." Webb then follows up rhetorically, "Why are these people (Yusuf and others) not pushed by the broader community? Because we are too busy arguing...these are people that we should strategically support" (Burk, 2014). However, there is a shift in his public messaging that happens right after Trump's 2016 election victory. In December 2016, Webb and Yusuf were both slated to speak at the RIS conference in Toronto where approximately 30,000 Muslims were in attendance. On stage, Yusuf was queried by one of his staunchest leftist critics about why he had been "absent" in endorsing Black Lives Matter (BLM). Situational awareness required a deft reply. The media cycle had been linking viral footage depicting police brutality against black males to Trump's victory in suggesting that a new looming era of virile white supremacy had come to power. Although Yusuf's answer did not elaborate on BLM specifically, he went into statistics suggesting that police shootings were less significant a problem than people from the same demographic backgrounds committing violent crimes against each other. Some interpreted this as dismissing the plight of black Americans. Webb, who was slated to speak next, decided to censure Yusuf on Facebook. The post went viral, and a media storm ensued. In the aftermath, Yusuf had all of his administrator-run social media websites deactivated and declined several interviews, and although the accounts would reopen years later, they never attracted the same large followings (Green, 2017). On The Mad Mamluks (2017) podcast, Webb acknowledged that he had unintentionally "created a fiasco" but argued that his Facebook post was necessary because he felt compelled "as a white man" when he perceived a few black audience members unnerved by hearing statistics reflecting "far-right social readings of America."

Tying this disagreement back into the emic event, Al-Arian's argument is that Muhammad Ali and Malcolm X represent "standing up against white supremacy and global empire" as well as "standing in solidarity with the struggles of black and brown people everywhere". However, the goal posts for defining racial equality and racism in the 1960s are radically different than those espoused today by intersectionality, critical race theory, and third wave anti-racism. These new woke discourses operate under the premise that the USA is, nowadays, a fundamentally and systemically racist country; however, these premises are based on subjective human experiences and perceptions of reality. Naturally, there is strong opposition to these views, especially among those perceiving the BLM movement as another iteration of Marxism that has appropriated the black struggle and amalgamated it with incongruous issues like transhumanism and transgenderism. Critics also note that BLM is founded by self-identified "trained Marxists" that have stealthily appropriated the civil rights legacy to attack traditional mores with institutional goals like "disrupting the Western-prescribed nuclear family structure" through queerness-affirming and disrupting "the tight grip of heteronormative thinking" (Steinbuch, 2020). Since third wave anti-racism shifts the focus away from equality and toward what it calls "equity," making essential societal divisions based on racial identity instead of the content of character, its redefinition of who is racist can be viewed as Manichean: 
"One who is supporting a racist policy through their actions or inaction or expressing a racist idea" (Kendi, 2019, p. 13).

On an issue like this, Webb and Yusuf's philosophical differences appear at variance. If simply being apolitical makes one a "racist," sundries can be guilted into supporting actions presented to them as "anti-racist" within a diaspora identifying themselves as black and brown. Webb, who comes out of a black American milieu, feels it necessary to identify himself within these frameworks, by his ethnicity, and he even promotes the reading of books like Robin DiAngelo's "White Fragility" to his audiences. In contrast, Yusuf could interpret Malcolm $\mathrm{X}$ 's warnings about grifters to mean that the very promulgation of third wave anti-racism is itself racist by different measures. While these philosophical differences are rooted in praxis, other differences are generational as exemplified by Webb choosing Facebook as a medium for his rebuke despite being physically present in the same auditorium. Elaborating on his rationale, Webb tells an interviewer:

Shaykh Hamza is not reachable. That's something I don't think people realize. I don't have his number...I'm asking everyone in the room outside of his inner circle, 'like how do you get in touch with Sheikh Hamza?' One activist in D.C. told me it's easier to get in touch with Obama.

With his personal emphasis on accessibility, Webb is highly critical of inaccessibility and the gatekeeping environment surrounding leadership. And it is after this event that Webb's public criticism of Yusuf visibly emerges. For instance, at The Islamic Center of Irvine on March 13, 2017, Webb (2017) states:

When I'm talking about tradition, I'm not talking about traditional Islam of America that makes us apolitical. I don't know what kind tradition that is! ... I'm not talking about Sufism that causes us to praise Trump and disparage black people! That has nothing to do with Sufism! Or works for the UAE! We're talking about independent religious scholars and leaders!

Corroborating Webb's criticism of Yusuf on this issue, in a February 8, 2020 Facebook post, Jonathan Brown republishes a photo of Bin Bayyah's son Cheikhna at the 2020 National Prayer Breakfast with Mike Pompeo with a caption which reads:

People need to be warned about what agenda people like Cheikhna are pushing, what they're working on and with whom... support for the regime that (among other things) continues to lobby the US and other western governments to declares MAINSTREAM Muslim organizations in our own countries as terrorist organizations.

American Muslims are generally critical of the UAE, not only for its foreign policy and participation in the war in Yemen, but also its claim that institutions, viewed as mainstream American Muslim charitable entities, are linked to extremist networks. Brown and Webb contend that if the UAE's policy 
recommendations are adopted in the USA, the slippery slope will inevitably indict everyday Muslim charitable behavior as terrorism. Therefore, the disagreement is both political and religious. Similarly, supporting the determination of an ethnically Arab secular nation-state in Palestine also rests on the religious desire of non-Arab Muslims to protect Al-Aqsa mosque in Jerusalem, Islam's 3rd holiest site. Despite this amalgamation of premises, Bazian, Brown, and Webb all make a theologically rooted insinuation that Yusuf may be participating as a cog in a process foreboded by eschatological prophecies about the grave loss of the mosque for Muslims.

\section{Appointment to the "Trump Panel"}

In combination to controversy about his international ties, Yusuf is also criticized for engaging the Trump administration. Yusuf's recognition as a public intellectual in influential conservative circles led to his appointment to an independent body assembled in 2019 by then Secretary of State, Mike Pompeo. The "Commission of Unalienable Rights" was announced to the chagrin of many liberals who saw the initiative as a "counterweight to an expansive liberal view on human rights" (Toosi, 2019). When the State Department quietly published a notice on the Federal Register about the commission on May 30, 2019 (The State Department, 2019), Politico picked it up immediately, citing activist concerns that “Talk of the 'nation's founding principles' and 'natural law' are coded signals of plans to focus less on protecting women and LGBT people". Neither Yusuf nor his organization released a statement to get ahead of the media onslaught that ensued once news of his inclusion on the commission circulated; therefore, one of the narratives abounding on social media, that he had "gone to work for Trump administration," remained unchallenged. The partisan anti-Trump sentiments were so widespread that several of Yusuf's long-time associates had reservations about the optics of being associated in any direct or indirect way to the Trump administration.

On August 15, 2019, Zaytuna College held a public panel titled "Rules of Engagement" (2019) that proposed to discuss the general rationale for why prominent American Muslims engage with the federal government. Based on the timing and phraseology of the event's announcement, it was presumed that Yusuf would offer an explanation for his engagement with the Trump administration. I flew into the Bay Area to attend. However, over an hour into the panel, there was no explicit statement from Yusuf on the matter, and right as the moderator was going to close the event a woman who identified herself as an activist spontaneously stood up in the third row and stridently confronted Yusuf, abruptly asking him pointblank why he was engaging with the Trump administration, how it would look to allies who protest the "Muslim ban," and in what capacity he was authorized to represent the Muslim community. Yusuf tranquilly thanked her and proceeded to chronicle a seven-minute elaboration of his approach on engagement. 
I went in ...in the Obama administration, we were very engaged because there was a lot more access; and I hope that engagement helped. In terms of this administration it has a wretched track record with our community, that's why I feel there should be some voices of countervailence just because one of the things that I've noted about being in the room, that by merely being in the room the conversation shifts.

Unlike the other diplomats, Yusuf made no public endorsements of political candidates or parties. In the past, he has suggested ignoring federal elections and focusing on local allies and municipalities with shared moral concerns. However, for many, Yusuf has become so cognitively associated to conservatives like Robert P. George or the late Sir Roger Scruton in recent years that some were surprised to hear that he had engaged with Democrats during Obama's tenure. It was also the first public denunciation many had heard him make about the Trump administration. However, pivoting out of the political into the metaphysical, Yusuf attempted to bolster his case by narrating one of the Prophetic traditions he attempts to root his approach in.

The Prophet said 'whoever wants to give advice to political authority, let him not do it openly'... And then he said 'if he listens the man gets the reward of giving good advice if they listen. If he doesn't, then you have just fulfilled a responsibility of just giving sincere advice'. So, that's all my intention is, is to give sincere advice. In terms of representing the community, I don't represent a community. I'm trying to represent an Islam that I studied for many years. And I'm committed to the religion. I see a very fragmented community.

\section{Conclusion}

So, what have we learned? American Muslims and their scholars are much more diverse in opinion than flattening media tropes and academic reporting would suggest. Furthermore, competing claims are made about the religious legacies of black American Muslims like Malcolm X and Muhammad Ali, and amidst moving tides reducing religion into an identity marker on par with identities linked to race or sexual preference, scholars are compelled to weigh in as terms and legacies are appropriated and renegotiated. Like the role of a diplomat, the job of public religious figures has been fundamentally changed with the proliferation of media technologies. From state-funded actors to ideologues with personal vendettas, nowadays, everyone can weigh in. Shakir and Jackson, for instance, were quick to show up on social media after an attack on their inherited legacies. And it would seem that in a mediascape dominated by effective monopolies with clear ideological biases that people of influence must engage these entities in order to lobby audiences. This ties into Webb's effectiveness on multiple platforms and his argument about access. While it is accepted that Islamic scholarship is principally a meritocratic pursuit with few barriers of entry, much of any contemporary scholar's effectiveness hinges on public perceptions and messaging, which are in turn heavily swayed by digital platforms. 
Moreover, communal consent requires consultation, which is contingent on a scholar's accessibility. Accordingly, while many would accept that Al-Arian's op-ed overstepped in areas, the concerns it raised deserve redress.

Still, for someone literate in media ecology, the choice to engage digital discourses remains a difficult and moral one. As a critic of ersatz culture whose favorite author G.K. Chesterton once argued, tolerance is the virtue of a man without convictions. Hence, Yusuf seems unlikely, in principle, to take to Twitter to defend actions he intentionally does in private, and while his decision may be as futile as the resistance the Ottomans displayed towards the printing press, it appears to be a conscious one. It could be posited that Yusuf's engagement fits under the center-right political wing of classical liberalism's paradigm, in contrast to Webb's affiliation to the center-left. On the other hand, positing this does not acknowledge that the wider shifting goalposts governing the public square in the woke era make it difficult to affirm that these designations still have meaning. For disparate reasons, Yusuf and Webb have both drawn the ire of critics while engaging spaces that jeopardize their own reputations and personal safety. However, as they have shifted from collaborators to intracommunal competitors, they represent a wider balkanization of thought that in many ways mirrors the political polarization that is happening in many other spaces.

\section{Compliance with ethical standards}

Competing Interests The author declares no competing interests.

\section{References}

Abu-Reem. (2007). 2 UPDATES! Muslim Matters. Retrieved from https://muslimmatters.org/2007/ 08/22/suhaib-webbs-departure-from-traditionalism/

Adar, S., \& Yenigün, H. (2019). A Muslim counter-hegemony?: Turkey's soft power strategies and Islamophobia. Jadaliyya. Retrieved from https://www.jadaliyya.com/Details/38646/A-Muslim-CounterHegemony-Turkey\%E2\%80\%99s-Soft-Power-Strategies-and-Islamophobia

AJ+. (2016). Meet Suhaib Webb, The ISIS-Blacklisted 'Snapchat Imam' . AJ+'s YouTube. Retrieved from https://www.youtube.com/watch?v=60CkEmXSYXw

Al-Arian, A. (2019). The political impotence of the Muslim American community. Al Jazeera. Retrieved from https://www.aljazeera.com/indepth/opinion/political-impotence-muslim-american-community190820151839919.html

Al-Azami, U. (2018). UAE's forum for 'promoting peace' is another cynical PR initiative. Middle East Eye. Retrieved from https://www.middleeasteye.net/opinion/uaes-forum-promoting-peace-anothercynical-pr-initiative

Barzegar, A. (2011). Discourse, Identity, and Community: Problems and Prospects in the Study of Islam in America. Muslim World, 532-534.

Benard, C. (2004). Civil Democratic Islam: Partners, Resources, and Strategies. RAND Corporation.

Berger, P. L. (2011). The sacred canopy: Elements of a sociological theory of religion. Open Road Media.

Blitzer, R. (2020). Biden campaign distances itself from former Women's March leader Sarsour after DNC appearance. Fox News. Retrieved from https://www.foxnews.com/politics/biden-campaigndistances-former-womens-march-leader-sarsour-dnc 
Brown, J. A. (2018). Keeping our eye on the ball: the problem with the UAE Summit. Muslim Matters. Retrieved January 8, 2020, from https://muslimmatters.org/2018/12/17/keeping-our-eye-on-the-ballthe-problem-with-the-uae-summit/

Brown, J. A. (2019). Jonathan Brown's Facebook page. Facebook. Retrieved January 20, 2020.

Burk, D. (2014). Imam: it's 'code red' for American Muslims. CNN. Retrieved from https://edition.cnn. com/2014/10/16/living/muslims-code-red/index.html

Carey, J. W. (1967). Harold Adams Innis and Marshal McLuhan. The Antioch Review, 27(Spring), 5-39.

Carey, J. W. (1970). The mythos of the electronic revolution. The American Scholar(Spring), 219-241.

CBC. (2016). Canadian scholar helped prepare Muhammad Ali's funeral. CBC News's YouTube. Retrieved from https://www.youtube.com/watch?v=gYJuQ-TYmEQ

Cormaic, R. M. (2016). Diplomats urged to 'open up' and tweet more. Irish Times. Retrieved from https:// www.irishtimes.com/news/politics/diplomats-urged-to-open-up-and-tweet-more-1.2771300

Daniels, T. P. (2019). Blackamerican Muslim scholars and leaders in New York City: sidelining Islamophobia and misrepresentations. American Journal of Islamic Sciences, 36(4), 61-88.

Fletcher, T. (2016). The Naked Diplomat: Power and Statecraft in the Digital Age. William Collins.

Gilens, M., \& Page, B. (2014). Testing theories of American Politics. Cambridge University Press.

Gittens, H., \& Dilanian, K. (2017). Trump takes jab at 'intelligence' officials for allegedly delaying 'Russian Hacking' briefing. NBC News. Retrieved from https://www.nbcnews.com/news/us-news/trumptakes-jab-intelligence-officials-allegedly-delaying-russian-hacking-briefing-n702906

Graham, D. A. (2016). How many Muslims will vote for Donald Trump? The Atlantic. Retrieved from https://www.theatlantic.com/politics/archive/2016/02/muslim-voters-2016/458691/

Green, E. (2017). Muslim Americans are united by Trump - and divided by race. The Atlantic. Retrieved from https://www.theatlantic.com/politics/archive/2017/03/muslim-americans-race/519282/

Greenwald, G. (2020). Glenn Greenwald - On The Beat - "YOUR WELCOME" Episode \#131. Michael Malice's YouTube. Retrieved from https://www.youtube.com/watch?v=cLPdI7jbVfM\&t=3s\&ab_ channel=MichaelMalice

Greenwald, G. (2021). Glenn Greenwald to RT. RT's YouTube. Retrieved from https://www.youtube.com/ watch?v=By-R7GrRz_0\&t=4s\&ab_channel=RT

Hallin, D. C. (1986). The uncensored war: The media and Vietnam. The University of California Press.

Hamad, S. (2019). Hamza Yusuf is not your friend. The New Arab. Retrieved from https://www.alaraby. co.uk/english/comment/2019/7/17/hamza-yusuf-is-not-your-friend

Hilal, M. (2019). It's time for Muslim Americans to condemn Hamza Yusuf. Al Jazeera. Retrieved from https://www.aljazeera.com/indepth/opinion/time-muslim-americans-condemn-hamza-yusuf$190715130254222 . h t m l$

Investor's Business Daily. (2018). Media bias: pretty much all of journalism now leans left, study shows. Investor's Business Daily. Retrieved from https://www.investors.com/politics/editorials/ media-bias-left-study/

Jackson, S. (2005). Islam and the Blackamerican. Oxford.

Jackson, S. (2009). Islam and the problem of black suffering. Oxford University Press.

Jackson, S. (2019). From demagoguery into the lizard's hole. ALIM. Retrieved from https://www. alimprogram.org/blog/from-demagoguery-into-the-lizards-hole-a-response-to-ali-al-arian

Junod, T. (2017). The greatest, at rest. ESPN. Retrieved from http://www.espn.com/espn/feature/story/_ id/19409912/the-planning-muhammad-ali-funeral

Kendi, I. X. (2019). How to be antiracist. Oneworld.

Khan. (2016). This imam delivers eight second Snapchat sermons. Quartz. Retrieved from https://qz. com/646902/this-imam-delivers-eight-second-snapchat-sermons/

Kirchgaessner, S. (2020). Reporter who wrote book on Saudi crown prince was allegedly targeted by hackers. The Guardian. Retrieved from https://www.theguardian.com/technology/2020/jan/28/ saudi-arabia-new-york-times-reporter-hacking-allegations-mbs

Latif, J. (2019). American Muslim character cancellation: framing engagement through the sphere of deviance. Media and Communication.

Leiby, R. (2002). Talking out of school; was an Islamic professor exercising his freedom or promoting terror? The Washington Post.

Lindsay, J., \& Pluckrose, H. (2020). Cynical theories. Pitchstone.

Lipka, M. (2017). Muslims and Islam: key findings in the U.S. and around the world. Washington D.C.: Pew Research .

Lukianoff, G., \& Haidt, J. (2019). The coddlingn of the American mind. Penguin Books. 
Lutz, A. (2012). These 6 corporations control 90\% of the media in America. Business Insider. Retrieved from https://www.businessinsider.com/these-6-corporations-control-90-of-the-media-in-america2012-6?op=1

Lynch, M. (2006). Voices of the new Arab public: Iraq, Al-Jazeera, and Middle East politics today. Columbia University.

Mogahed, D., \& Chouhoud, Y. (2017). American Muslim Poll 2017: Muslims at the crossroads. Institute for Social Policy and Understanding.

Mohamed, B., \& Diamant, J. (2019). Black Muslims account for a fifth of all U.S. Muslims, and about half are converts to Islam. Pew Research. Retrieved from https://www.pewresearch.org/fact-tank/ 2019/01/17/black-muslims-account-for-a-fifth-of-all-u-s-muslims-and-about-half-are-convertsto-islam/

Newlon, B. P. (2017). American Muslim Networks and Neotraditionalism. University of California Santa Barbara.

O'Sullivan, J. (2001). If you hate the west, emigrate to a Muslim country. The Guardian. Retrieved from https://www.theguardian.com/world/2001/oct/08/religion.uk

Patterson, T. E. (2017). News coverage of Donald Trump's first 100 days. Harvard Kennedy School.

Pew Research Center. (2017a). U.S. Muslims concerned about their place in society, but continue to believe in the American Dream. Pew Research Center. Retrieved from https://www.pewforum.org/2017/07/26/ demographic-portrait-of-muslim-americans/

Pew Research Center. (2017b). U.S. Muslims concerned about their place in society, but continue to believe in the American Dream. Pew Research Center. Retrieved from https://www.pewforum.org/2017/07/26/ findings-from-pew-research-centers-2017-survey-of-us-muslims/

Pew Research Center. (2018). Muslims in America. Pew Research Center. Retrieved from https://www. pewforum.org/essay/muslims-in-america-immigrants-and-those-born-in-u-s-see-life-differentlyin-many-ways/

Philpot, T. (2017). Conservative but not Republican: The paradox of party identification and ideology among African Americans. Cambridge University Press.

Rabasa, A., Benard, C., Schwartz, L. H., \& Sickle, P. (2007). Building Moderate Muslim Networks. RAND Corporation.

Robertson, D. (2018). How an obscure conservative theory became the Trump era's go-to nerd phrase. Politico. Retrieved from https://www.politico.com/magazine/story/2018/02/25/overton-window-explaineddefinition-meaning-217010

Robinson, E. (2010). Disintegration: the splintering of black America. Anchor.

Royer, I. (2019). Ismail Royer's Twitter page. Twitter. Retrieved from https://twitter.com/IsmailRoyer/status/ 1185031622162292736

Sach, M. (2019). Why the democrats have shifted left over the last 30 years. FiveThirtyEight. Retrieved from https://fivethirtyeight.com/features/why-the-democrats-have-shifted-left-over-the-last-30-years/

Schumer, C. (2017). Chuck Schumer: Donald Trump captured by hard right I Rachel Maddow I MSNBC. MSNBC's YouTube. Retrieved from https://www.youtube.com/watch?v=c3p2zKPQSgI\&t=11s\&ab_ channel=MSNBC

Shakir, Z. (2019). A response to Ali Al-Arian. Retrieved January 8, 2020, from Imam Zaid Shakir's Facebook page.

Shepard, W. (1987). Islam and ideology: towards a typology. International Journal of Middle East Studies, 319.

Sheresthova, S. (2016). Between storytelling and surveillance. In S. S.-T.-V. Henry Jenkins, By Any Media Necessary: The New Youth Activism (pp. 149-186). New York: NYU Press.

Sowell, T. (2004). Affirmative Action Around the World: An Empirical Study. Yale University Press.

Steinbuch, Y. (2020). Black Lives Matter co-founder describes herself as 'trained Marxist'. New York Post. Retrieved from https://nypost.com/2020/06/25/blm-co-founder-describes-herself-as-trained-marxist/

Stern, M. (2020). Beyond postmodern: the Neoliberal roots of woke cancel culture. Aero Magezine.

Tadros, S. (2014). Reflections on the revolution in Egypt. Hoover Press.

Tadros, S. (2015). The brotherhood divided. Hudson Institute. Retrieved from https://www.hudson.org/ research/11530-the-brotherhood-divided

Taibbi, M. (2019). Hate Inc.: why today's media makes us despise one another. OR Books.

The Economist. (2019). Why American Muslims lean leftwards for 2020. The Economist. Retrieved from https:/www.economist.com/erasmus/2019/09/22/why-american-muslims-lean-leftwards-for-2020

The Mad Mamluks. (2017). EP 056 - The Snapchat Imam: Suhaib Webb. The Mad Mamluk's YouTube. Retrieved from https://www.youtube.com/watch?v=R9gdbfAxAkk 
The State Department. (2019). Department of State Commission on Unalienable Rights. Federal Register. Retrieved January 5, 2020, from https://www.federalregister.gov/documents/2019/05/30/2019-11300/ department-of-state-commission-on-unalienable-rights

Toosi, N. (2019). Trump's 'natural law' human rights panel readies for launch. Politico. Retrieved from https://www.politico.com/story/2019/07/03/human-rights-panel-1398636

Tripp, C. (2006). Islam and the moral economy. Cambridge University Press.

U.S. Department of Defense. (2016). Centcom Officials Release Iraq, Syria Civilian Casualty Assessments. U.S. Central Command. Retrieved January 8, 2020, from https:/www.defense.gov/Explore/News/ Article/Article/1000962/centcom-officials-release-iraq-syria-civilian-casualty-assessments/

Wangsness, L. (2013). In life and words, Muslim leader bridges cultures. The Boston Globe. Retrieved from https://www.bostonglobe.com/metro/2013/05/11/imam-william-suhaib-webb-emerges-face-bostonmuslim-community-time-crisis/Kd8v0O48vkHSZAnOpYCqOI/story.html

Webb, S. (2011). Fasting, materialism and time management. Zaytuna College's YouTube. Retrieved from https://www.youtube.com/watch?v=cDfO46rl0_g

Webb, S. (2017). The masses creed. Icoitv's YouTube. Retrieved from https://www.youtube.com/watch?v= 8yivLGbI2SM\&t $=1368 \mathrm{~s}$

Weiss, B. (2020a). Joe Rogan Is The New Mainstream Media. The New York Times. Retrieved from https:// www.nytimes.com/2020/05/25/opinion/joe-rogan-spotify-podcast.html

Weiss, B. (2020b). Bari Weiss on why she left the New York Times. The New York Post. Retrieved from https://nypost.com/2020/07/14/bari-weiss-on-why-she-left-the-new-york-times/

White, I., \& Laird, C. (2020a). Steadfast Democrats. Princeton University Press.

White, I., \& Laird, C. (2020b). Why are Blacks Democrats? Princeton University Press. Retrieved from https://press.princeton.edu/ideas/why-are-blacks-democrats

Younas, S. (2019). Salman Younas's Twitter page. Twitter. Retrieved from https://twitter.com/salyounas/status/ 1165252845987344384

Yusuf, H. (2019). Rules of engagement. Zaytuna College's YouTube. Retrieved from https://www.youtube.

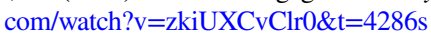

Publisher's Note Springer Nature remains neutral with regard to jurisdictional claims in published maps and institutional affiliations. 